\title{
El fenómeno de la mirada y el concepto de lugar. Una propuesta de aprendizaje basado en proyecto con videocreación e Internet
}

\author{
The phenomenon of the gaze and the concept of space. A project- \\ based learning proposal with videocreation and Internet
}

Javier DOMíNGUEZ. Universidad de León (España).javierdzm@gmail.com

Resumen: Proponemos una investigación fundamentada en los conceptos de mirada y de lugar para aplicar éstos al mundo-imagen de Internet. Un entorno digital, el ciberespacio, donde las imágenes-archivos comprenden un nuevo estatus y régimen visual: fuertemente mediatizado, y que reta a desarrollar posiciones críticas y creativas que necesitamos. Esta investigación teórica ha venido aplicándose en prácticas artísticas que conjugan la videocreación y las imágenes de otros lugares del mundo, azarosamente halladas, y capturadas de la aplicación Street View del tecnológico Google. Con una metodología activa de aprendizaje basado en proyecto, recurrimos a profundizar en un concepto de mirada responsable que toma conciencia de su poder para decidir los accesos al régimen visual. Y proponemos emplear estas herramientas con los objetivos pedagógicos de entrenar un lenguaje estético y de generar un discurso ético-político a partir de las narrativas visuales; de modo que el estudiante vea concernidos sus planos creativo y crítico como ciudadano. Estas fuentes visuales propias (videocración con dispositivo móvil) y ajenas (la Red) se disponen, en la elaboración del proyecto narrativo, para construir relatos visuales donde podamos otorgar un sentido a los fragmentos de realidad que se nos aparecen; de modo que el estudiante resignifique los valores jugando con las presencias (lo ostensivo de la imagen) y las ausencias (inferidas o imaginadas). Un juego cuyo objetivo segundo promueve el pensar, críticamente, la identidad tal como se aparece en las pantallas, y lo desapercibido que queda en sus márgenes.

Palabras clave: educación artística, mirada, internet, proyecto, videocreación, narrativa visual 


\begin{abstract}
We propose a research based on the concepts of gaze and space to apply them to the world-image of the Internet. Cyberspace is a digital context where images-files comprise a new status and visual regime: that is strongly mediatized and challenges to develop the critical and creative position we need. This theoretical research has been applied in artistic practices that combine videocreation and images from other places in the world found by chance on the app Street View by Google. We resort to deepening a concept of responsible gaze that becomes aware of its power to decide the access to the visual regime with an active project-based learning methodology. And we propose to use these tools with the pedagogical objectives of training an aesthetic language and generating an ethical-political discourse from visual stories; so that the student can see his creative and critical plans involved as a citizen. These own visual sources (videocreation with mobile device) and others (Internet) are arranged, in developing the project, to build visual stories where we can give meaning to the fragments of reality that appear to us; in such a way that the student redefines the values by playing with the presences (the ostensiveness of the image) and absences (inferred or imagined). A game whose second objective promotes thinking, critically, the identity appeared on screens and the unnoticed on their margins.
\end{abstract}

Keywords: arts education, gaze, internet, project, videocreation, visual story

\title{
Introducción a las nociones de mirada y lugar. Consideraciones teóricas
}

Cuando emprendemos un corpus de contenidos en educación artística, en nivel universitario, partimos de ciertos presupuestos sin los cuales no habría posibilidad de llegar a destinos favorables para cuestionarnos. Necesitamos componer un marco que aclare a nuestros estudiantes y vehicule, la enseñanza artística, hacia el lugar de sus nuevos interrogantes.

Con este propósito desligamos, en primer lugar, el fenómeno estético de su exclusiva función mimética, y lo abordamos más allá (y más acá) de su mera utilidad representativa, analógica, como desdoblamiento platónico de la realidad fenoménica. Lo que generalmente se aborda, desde un enfoque formalista, y atendiendo las consideraciones icónicas que permiten, por un razonamiento elemental, distinguir y comprender lo figurativo y lo abstracto en una matizadísima escala de iconicidad (Bozal, 1987; Jiménez, 2002, pp. 75-81). Esta exposición permite el anclaje de nociones básicas que el estudiante ya atribuye a la imagen estética: las de simulacro y ficción; lo cual necesitaremos para posteriormente interrogarnos por el sentido de las mismas, si las llevamos a últimas consecuencias, en un replanteamiento de la naturaleza de lo real-dispuesto y de lo pensado-creado-narrado. Ríos que afluyen y coinciden comúnmente en imagen, en ese dispositivo visual con que trabajamos. 
En este sentido, la enseñanza del desligamiento de la función mimética, no es tanto un propósito formal como la base para introducirles al terreno fértil de los interrogantes sobre todas las dimensiones (y misiones) posibles del hecho artístico.

Las presentaciones docentes que sitúan, el Romanticismo y las Vanguardias, como basamentos históricos de la autorreferencialidad del arte (Klee, 2007; Brihuega, 2002, pp. 229-248), sirven para poner en contexto la quiebra de todo un modelo de espacio ilusionista o "teatral" (Fried, 2004, p. 47) con la superación del ocularcentrismo. Este punto de partida favorece al alumnado universitario del área artística (en el Grado de Educación Primaria) en su emprendimiento de un viaje personal, con capacidad crítica, y desembarazado de los estereotipos con que más frecuentemente han convivido en una visión sesgada del hecho artístico. No se trata de establecer un rechazo apriorístico al objeto mimético del arte, sino de comprender que los fundamentos y juegos argumentales de éste, son inmensamente plurales y complejos.

Desligados de una obediencia a la re-presentación, a replicar el percepto visual, los estudiantes pueden integrar sus motivaciones creativas ya sea en un medio dibujístico, pictórico, fotográfico o videográfico. Tanto en un medio plástico como en un medio digital audiovisual, la superación del paradigma mimético será la clave para incorporar, la autorreferencialidad, en sus distintos alcances y vertientes: la interioridad psicológica (aprendido del histórico modelo romántico), o el juego del mensaje cifrado (aprendido del otro histórico modelo vanguardista); bien la expresionista, o bien la vertiente semiótica y comunicacional.

Allí, en el marco de tales enfoques básicos para una comprensión del fenómeno estético, podrán utilizar el espacio creado visualmente (imagen) como nuevo lugar en que situar su intención; como lugar con que permitir que emerjan nuevos elementos, y así dejar aparecer el "sentido" que otorgan a la realidad para resignificarla (Liddell, 2015, pp. 45-57). El sentido, tal como bien lo expone la teórica del arte y dramaturga contemporánea Angélica Liddell: aquello que se crea y revela sólo en el propio lenguaje tejido para expresarnos; lo que se ofrece a un espectador por venir (o no) y abre a la interpretación.

Cuando el estudiante experimenta, en el ámbito de la educación artística, la sola posibilidad de trazar este nuevo proceso -que ya no sólo asume sino resignifica, zarandea, muta o critica la realidad-, genera un interesante espacio de tensión con los otros y consigo mismo. Un nuevo espacio, lugar sentido que sólo puede fructificar en tanto la mirada del pensamiento crítico se siente concernida. Lo que nos obliga a manejar, de partida, estos conceptos, para con ellos poder trasladarlos a una experiencia artística integral y personal (donde el solo desarrollo de unas habilidades que queden desintegradas no haga que la unidad intencional se disuelva, y donde la implicación de la propia mirada sea un motor indispensable). 
En lo tocante a la noción de mirada, conviene recordar que la "doble dimensión" del cuerpo-sujeto como cuerpo que pertenece al mundo y como sujeto que dota de sentido al mundo (Merleau-Ponty, 2010, pp. 99-118) nos sirve de esquema elemental; o bien, como primer ejercicio de reconocimiento y autocomprensión del papel que todos desempeñamos, también y cuanto más, en el aprendizaje de nuestro ámbito de conocimiento. Tal cuerpo, una vez ha desarrollado su capacidad de identificar puntos de anclaje, asimila un espacio que siempre se despliega o da como aquel espacio-situación que vivimos. Este principio fenomenológico de la percepción importa para nuestro abordaje experiencial, en tanto la incursión de cada persona en un espacio no ha de juzgarse como una intromisión sino como esa necesaria integración vivencial. El espacio no es sólo físico sino situacionalvivencial; $y$, por ende, compromete también la interacción social y lo ético-político. Es un espacio también crítico -sin duda, intelectual, en donde nuestra intelección del espacio lo conforma-.

Muchas relaciones visuales responden a esta concepción integral y holística, social y crítica, de manera que logramos subjetivizarnos y objetivizarnos -al unísono- en el doble juego que ya señala Merleau-Ponty. Una suerte de red de redes (de la que Internet podría resultarnos la mejor metáfora, y de la que es encarnación) por la que el cuerpo fenoménico se vincula al mundo y vincula éste con él. Esta vinculación sería imposible si no se comprometiera una mirada que nos pertenece y que nos afecta en la medida que la compartimos.

Si incorporamos la afirmación sostenida por Bergson, "no hay percepción que no esté impregnada de recuerdos" (Bergson, 2001, p. 183), elucidamos un ingrediente inseparable de la fórmula de esta mirada a que nos referimos. Con esto, se establece una especie de bifurcación en las imágenes que componen nuestro universo visual. Las imágenes que tienen lugar en mi cuerpo son, en primer lugar, un proceso anónimo por el que invaden las imágenes naturales, para diferenciarlas enseguida como percepción interesada y como acción. Lo que nos permite hacerlas entender, a nuestros estudiantes, como imágenes vivientes -en términos bergsonianos- con su raíz en la memoria.

Sin embargo, conviene recordar que debemos hablar de mirada más allá de su dimensión contemplativa: entendiéndola como acto de un nuevo juego de indagar y preguntarse. Esto que, los primeros artistas de las vanguardias, inauguraron con lo que en aquel panorama convulso vino a llamarse "azar subjetivo" (ingrediente dadaísta) y "azar objetivo" (fundamento surrealista); un caldo de ideas programáticas de las que los propios artistas dieron buen testimonio -lo que conviene que el estudiante tenga presente- (González, Calvo y Marchán, 2009). En esta progresión del concepto o del acto de la mirada, el propio Jacques Aumont lo ha configurado en 3 fases analíticas: el funcionamiento ocular-perceptivo; el paso mental de lo "visible" a lo "visual" más allá del órgano sensorial; y un último salto de lo "visual" a lo "imaginario" que transforma lo evidente en material para la interpretación como acto intencional (Aumont, 1992). 
Norman Bryson postula el ocaso de esa mirada contemplativa; lo que estrechamente se relaciona con la problemática de lo visual que nos ocupa. La disposición de las imágenes, antes de la citada ruptura con aquel espacio tradicional, ya nos informaba de una mirada escenógrafa y espectadora que disponía controladamente para contemplar. Comprender esta ruptura es fundamental para reubicar el fenómeno artístico, antes fijado en un acto organizativo, en una nueva o distinta acción lúdica: la del juego estético, y el vértigo de nuestra "participación jugadora", implicados (Gadamer, 2010, pp. 32-33). De ahí que coincida el período de los ready-mades duchampianos, por ejemplo, donde la práctica artística ha dejado de producir imágenes que contienen espacios para directamente producir espacios.

Lo que le sucede a esto, es propuesto como una nueva tipología de la visión, ya no central frente a una imagen, sino indagadora ante piezas artísticas ricas en valores táctiles y gestuales que indican acertijos o exigen distintas orientaciones espaciocorporales. Lo que podría denominarse vistazo en castellano, glance en inglés, coup d'oeil en francés, o Augenblick en alemán (Bryson, 1991, pp. 98-139). En el concepto brysoniano de "vistazo" podríamos leer y resumir cuatro contraposiciones: $1^{\text {a) }}$ un esfuerzo comprensivo que exige la imagen al no haber sido ordenada para instruirnos; lo que supone alterarla interrumpiendo su flujo y prestarle una atención de vivo y profundo calado (algo que se exacerba en el caso de Internet); $2^{a}$ ) búsqueda excéntrica de elementos fuera del encuadre y a los que la imagen es capaz de remitirnos sin determinarlos; lo que planta la semilla a un despliegue narrativo por hacer; $3^{\mathrm{a}}$ ) el desate de la sospecha ante la falta de certidumbres (visualmente explícitas) y un nuevo campo visual sembrado de incógnitas; y $4^{\mathrm{a}}$ ) un consecuente despunte de lo terrible ante la falta de constataciones por las que, antes, consagrábamos con la mirada lo que advertían los ojos; lo que lleva a una nueva situación visual donde todo argumento posible queda por encajar.

Este nuevo marco digresivo no sólo va a fracturar las lógicas anteriores, sino que también altera de raíz los estatus tanto de las imágenes como de nuestro rol locativo y hermenéutico respecto de ellas: ¿qué nuevo lugar ocupamos ahora? ¿y hacia dónde dirigirnos en busca de la interpretación?

Si conviene traer a colación un autor, en el historiador y teórico del arte Francastel hallamos una propuesta conceptual de relevancia: la de lugar. Concepto que bucea en los distintos factores que vinculan el fenómeno artístico y la sociedad, sin que la imagen se vea reducida a lo ostensivo en ella. Aunque el pensador francés ligara esta noción al período histórico renacentista, de su análisis nos interesa el abordaje del arte como un artefacto que otorga su propio sentido del mundo en que vive. Un sentido, al que ya nos hemos referido, que sólo el campo estético puede cubrir, y que se atribuye a las imágenes que únicamente comportan este poder o capacidad. En ellas, comprendemos un lugar de enlaces o relevos entre el productor visual y el espectador; de modo que se crea un espacio comunicacional, un lugar de propuestas y réplicas, donde hacerse posible la interlocución. 
DOMÍNGUEZ / El fenómeno de la mirada y el concepto de lugar. Una propuesta de aprendizaje basado en proyecto con videocreación e Internet

La imagen $[\ldots]$ lejos de constituir un duplicado de una realidad dada y percibida, es una suerte de 'relevo', de lugar de enlaces [...] sirve de punto de referencia, de punto de apoyo, a las actividades interpretativas tanto del espectador como del artista que la ha inventado. Unos y otros se encuentran [...] en un lugar abstracto irreal, imposible, condicionado por el lugar tangible [...] este lugar determina orientaciones del pensamiento. (Francastel, 1988, p. 295)

De tal modo que, como abogamos, la enseñanza artística procure un enfoque nada inocente de las imágenes; en que éstas poseen la carga suficiente para interpelar a otros o interpelarnos. Del lugar material o tangible (bien sea un lienzo matérico o de píxeles que transitan por la Red) al lugar imaginario donde se activan los pensamientos y recuerdos. Con esta consideración, de la que Francastel fue pionero, componemos un breve marco teórico con que aterrizar a la tromba de imágenes que, por instantáneas, hoy casi parpadean en las pantallas virtuales. Es necesario fijar unos conceptos que permitirán a los estudiantes, como válidas herramientas, no caer en la hipnótica pasividad a que conduce en muchos casos el modo en que hoy transitan las imágenes por Internet.

Imágenes que no deben quedar indiferentes o cerradas incuestionablemente; sino que, al modo de ver del propio Umberto Eco, encarnan "obras abiertas". Una sugerente posición que nos atrevemos a resumir en tres propósitos: $1^{\circ}$ ) asumir la crisis de una imagen unitaria y definitiva, ya imposible dada la enorme discontinuidad que se reitera entre los fenómenos; $2^{\circ}$ ) entender que, así, la imagen artística, ya no sugiere un objeto de visión como más bien propone un modo de ver aquello en que se vive; y $3^{\circ}$ ) de modo que la imagen misma es una discontinuidad narrativa, cediéndonos la posibilidad o el esquema que nos permita comprender nuevos aspectos del mundo (Eco, 1990, p. 180).

Este marco referencial contribuye a entender que las imágenes que emergen, en un terreno tan amplísimo y heterogéneo, ya no tienen que objetivizar (reducir o simplificar) enunciados objetivos o universales del mundo, sino que revelan cuánto de impensado aún hay bajo esa firme y compacta esfera de lo real que tradicionalmente nos han transmitido desde muy distintas disciplinas. En lugar de obedecer o apuntar hacia esa dirección, el campo estético y artístico (prácticas humanas) se ocupa de señalar más bien las grietas de los modelos con que hayan tratado de exponernos lo real. En lo que, el rol docente en educación artística y visual, es un agente activo con óptimas posibilidades, porque "el modelo de enseñanza [...] implica un activismo crítico y una necesidad de participación con credulidad en lo que se hace [...] La clave inicial radica en mantener valores que creamos válidos, no como opción, sino como certeza" (Villalba, 2012, § 8). Lo que ha implicado, en nuestro caso, una estrategia metodológica que incluya el medio-lenguaje audiovisual, la coparticipación de material visual dado en Internet, y por supuesto diversificar las opciones temáticas admisibles de manera que el alumnado pueda, identificar relatos latentes (en aquellos márgenes de las imágenes-archivos), y construir narrativas. Por lo que debe estimarse tanto lo presente en una imagen (lo perceptivamente dado 
en su encuadre) como lo ausente y que bien podemos saber inferir en un acto crítico de interpretación y compromiso. Porque, en este contexto fuertemente biopolítico que se respira y visibiliza en la Red de redes, la implicación ética y sociopolítica será un factor terminal que de sentido a las propuestas y prácticas artísticas que se lleven a cabo. A fin de cuentas, para que nuestra mirada sustancie aportes sin compraventa, y por tanto ocupe o más bien cree ese lugar pre-indeterminado, se trata de "conectar con la promoción de un discurso congruente e inmediato entre los procesos de aprendizaje de carácter artístico y su probable trascendencia ética" (Villalba, 2017, p. 182).

\section{Otras consideraciones sobre las presencias y ausencias en el 'lugar de la imagen'}

En un lacónico repaso que se haga a las teorías de Francastel, Eco, Mieke Bal o el propio Gombrich, por citar algunos primeros autores implicados, en común ceden un protagonismo singular a la mirada. La problemática de lo visual viene de largo despertando atención a la cuestión del "tiempo" que se inquiere más allá de la imagen (como mero percepto visual, en su propio esencialismo visual). Ese desplegado tiempo siempre va a sugerirnos un hilo narrativo del que, la imagen, no puede dar entero o directo testimonio; no contiene en sí la capacidad de explicitarlo, pero sí de hacerlo implícito como la llave que abre la cerradura de una historia latente. Situamos así, al alumnado, ante el potencial narrativo de las imágenes artísticas que, o bien documentan, o bien sirven para evocar poéticamente el mensaje o la crítica pretendida desde la autosuficiencia metalingüística. Ese lugar de interpelación, o interlocución, al que antes venimos a referirnos.

Ese rasgo temporal, que se da en lo visual y trasciende lo visual, implica entonces ausencias además de las presencias (a veces se pueden inferir; otras, quedan abiertas al recuerdo o al ojo crítico). Las presencias de los cuerpos y los signos (cuerpos de la evidencia, y símbolos o cifras de mensajes) concitan en la imagen el caldo de cultivo para que pensemos en sus márgenes. Se trata, insistimos, de dejar de pensar las imágenes reducidas formalmente a lo que quede evidenciado en sus finitos encuadres. Allí en la imagen, no ya artística (a saber, en el flujo deliberado de imágenes que circulan en Internet) sino mirada desde una sensibilidad (que es estética, es política porque está politizada, y crítica porque es interpelada), se produce el conflicto temporal entre el instante y la memoria; lo instantáneo de su captura, y el andamiaje de recuerdos involucrados en esa mirada concernida, sensible e intelectual (no indiferente ni acrítica). Lo que supone un camino de avance para toda alumna y alumno que afronte, novedosamente, conceptos y prácticas artísticas en esta época de indiscriminada saturación visual.

Internet ha dado un marco en que cohabitarnos, visibilizarnos y pensarnos; esto es un hecho que escapa a cualquier voluntad que siquiera trate de sopesar sus ventajas y contrapartidas. En su flujo saturado de imágenes, en cascada, no podemos hacer 
DOMÍNGUEZ / El fenómeno de la mirada y el concepto de lugar. Una propuesta de aprendizaje basado en proyecto con videocreación e Internet

otra cosa que utilizar esa cascada visual para entrenar nuestra capacidad -a la que equivale llamar crítica y llamarla creativa-. Hemos venido proponiendo utilizar el manantial de imágenes-archivos que hay en el cibermundo (y al que llegamos a través de la Web o triple $\mathrm{W}$ desde que en los años 90 del pasado siglo la crearan Berners-Lee y Cailliau). En ese manantial del que salió el Net.Art por ejemplo, se ha atravesado por una serie de fases ya descritas, desde la Web 1.0 hasta la Web 3.0, para consolidar rasgos como la participación colectiva y colaborativa, o la accesibilidad de datos mediante una web semántica (Escaño, 2010, pp. 136-141). El problema que esto contrae es, efectivamente, el germen de especulaciones y predicciones sobre unos usuarios (lo que nos incluye y engloba a todos) a los que se predeterminan los caminos por los que navegar. De ahí que la Educación Artística sea el área de conocimiento universitaria oportuna para brindar posibilidades de sobreponerse y entrenarse: utilizando las imágenes dadas para pensar en sus márgenes, e integrándolas también con nuestras imágenes y narrativas audiovisuales creadas. Las piezas se dispersan en la Red, pero sólo puede ser nuestro el relato que a partir de ellas construyamos, probando a manejarnos con las nociones antes referidas de mirada, intelección o compromiso en un ejercicio a la par individual y colectivo, tanto estético y ético como también político y fuertemente mediatizado.

Si efectivamente Internet describe una época en que cohabitarnos, y reflexionar sobre qué motores o criterios deciden lo que se visibiliza e invisibiliza, primero debemos aclarar al estudiante que el hecho visual como perceptiva y tradicionalmente se ha concebido ya caducó. En este escenario virtual, los intangibles copan nuestra mirada y establecen -o más bien delatan- un "régimen escópico" que merece señalarse en relación con el contexto biopolítico que vivimos, y no sólo en que vivimos situándonos simplemente, puesto que los medios de producción y difusión visuales definen marcos o regímenes donde poder hacer narrativas visuales (Brea, 2007 , pp. 146-163; 2010). Esta advertencia aclara previamente que las cosas ya no son sólo "materia, en su fisicidad no mediatizada [y] en su forma de comparecer en las pantallas que conforman nuestro ecosistema informacional, porque la apariencia es hoy, ante todo, aparición en pantalla" (Martín Prada, 2018, p. 19). En palabras que siguen: "Más allá de nuestra materialidad o de nuestra conciencia, seríamos también nuestra manera de darnos a ver, de comparecer ante los otros, de presentarnos visualmente" (ibidem).

Cuando antes hemos señalado la memoria como factor clave de la mirada, y hemos dirigido el planteamiento a la relevancia de los recuerdos, lo hacíamos conscientes de la problemática del ciberespacio según el cual la memoria reposada es combatida, permanentemente, con la caducidad de lo instantáneo. Las imágenesarchivos fluyen como referimos porque son documentos volátiles que aparecen y desaparecen en la pantalla en tanto se vuelven accesibles o inaccesibles por la fuerza de la actualización que impera en Internet. En este punto, Martín Prada señala como "imposible evitar ya el preguntarnos por una nueva kairología visual, es decir, qué detener, dónde poner nuestra atención en ese fluir [...] ante nuestros ojos" 
(ibidem, p. 26). Pues aquí se decide lo que se incorporará a nuestra memoria y, en consecuencia, al testimonio y al relato que cedamos, por ejemplo, en las creaciones audiovisuales propuestas al estudiante. Esta dinámica visual parece que dificulta, pero no es sino un reto propio del régimen visual de Internet para hacer nuestras propias narrativas; en tanto en cuanto se produce un juego entre cuerpos presentes y otros cuerpos o acciones ausentes que tejerán posibles argumentos, como si cada alumna y alumno tuviera el desafío de crear sinopsis literario-cinematográficas con los fragmentos de realidad dados. Les venimos proponiendo así un proceso: un hallazgo; una intuición; una crítica; un relato.

\section{El sentido de una propuesta, de videocreación e imágenes-archivos, como ejemplo de poder y visibilidad en Internet}

En la asignatura de Educación Plástica y Visual que nuestra área universitaria imparte en el Grado en Educación Primaria, se ha probado una experiencia, fundamentada en lo anterior, tanto en las universidades de Sevilla y de León, cuyos objetivos pedagógicos han centrado: entrenar un lenguaje estético en el régimen de lo visual, y generar un discurso ético-político a partir de las narrativas visuales; de modo que el estudiante vea concernidos sus planos creativo y crítico como ciudadano. Para cumplir el primer objetivo, se planifica una actividad en tres fases que a continuación describiremos. Y el segundo objetivo es cubierto desde el principio de un proyecto en que cada decisión contribuirá al sentido del relato visual que finalmente se haya construido. Para su explicitación, estos relatos visuales (que, como detallamos, conjugan videocreación e Internet) dan lugar a la posterior exposición y discusión colectiva en clase, donde las narrativas creadas sirven tanto para defender decisiones tomadas como para abrir interrogantes que, precisamente, reafirman la capacidad de cuestionar los distintos caminos y discursos.

Cuando ha tenido mayor peso en otras disciplinas la idea de una realidad objetiva y exterior a nosotros (esa firme y compacta esfera que dijimos), la enseñanza artística ha tomado la solución alternativa fomentando, desde el Construccionismo, la

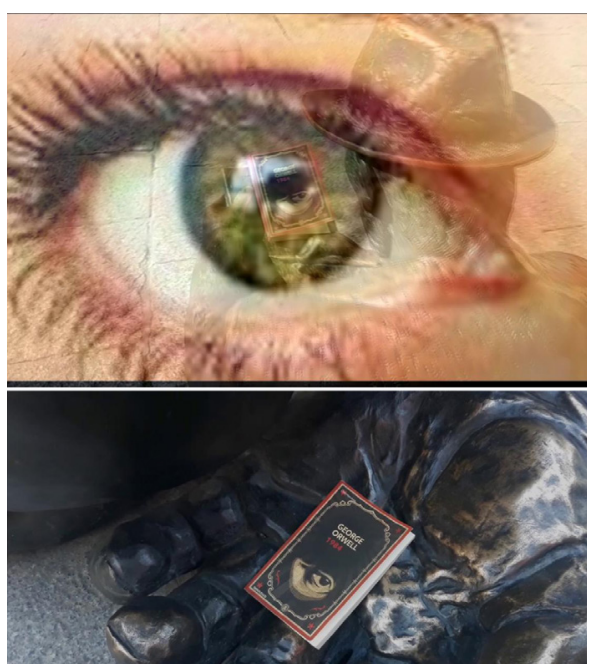
premisa de que nosotros tomamos la decisión de aquello que (finalmente o en principio) articulará nuestra vivencia y pensamiento. En torno a la mitad del pasado siglo XX, ya se dieron contribuciones que hoy no podemos dejar de citar y resituar en el centro del asunto: y es que "la realidad no es externa [...] existe en la mente humana y en ningún otro sitio" (Orwell, [1948] 1983, p. 120); así

Figura 1. (Superior) Fotograma de creación en vídeo de estiduantes, con libro "1984" de G. Orwell en la estatua de A. Gaudí situada en León (España).

Figura 2. (Inferior) Fotografía de estudiantes, con mismo libro sobre dicha escultura en brnce. 2019. 
como todo lo vivido ha sido trasladado a una suerte de representación espectacular (Debord, [1967] 2016). Lo que nos hace responsables y a su vez nos deja expuestos, visibilizados mediáticamente, sin que haya relato, presencia ni espectador inocente e inexorable. En 1958 Mark Rothko ironizaba preguntándose: "Si Cristo en la cruz hubiera abierto los ojos, ¿habría podido creer en los espectadores?" (Rothko, 2007, p. 186). Aunque el artista letón inscribía este comentario en referencia a la credibilidad teatral de aquella imagen-simulacro, que al principio expusimos, ahora la frase reactiva nuestro pensamiento crítico hacia esta era de ciberespacio en que vigilancia y espectacularidad han tocado techos éticos y biopolíticos. Una cuestión que no puede soslayarse en el campo de la enseñanza artística y en lo que ésta comporta para el estudiante. Cuando el acceso al régimen visible está en cuestión, entra en juego incluso la credibilidad de lo real; lo que niega al espectador inocente, y afirma toda mirada humana como ese acto ideológico, político, mediatizado por este mundo-interfaz al que subyacen "decisiones" y "relaciones de poder" (Escaño, 2019 , p. 255). Y cuando hablamos de la Web (tanto la anterior 2.0 como la 3.0 ya mencionadas) lo hacemos considerando, lo primero, las redes sociales y las aplicaciones móviles que nos cohabitan como apéndices propios. Es en este marco relacional en que jugamos un ambiguo rol: consumar lo dispuesto, y dar testimonio de lo real. De ahí que vengamos proponiendo conjugar dos fuentes de material visual para construir narrativas: la propia videocreación, y las imágenes-archivos capturables de la aplicación Street View.

Esta aplicación se incorpora en el popularizado programa de geomática Google Earth; el cual inicialmente fue creado por la inteligencia norteamericana, para luego ser adquirido por el gigante tecnológico que todos utilizamos en nuestras búsquedas de información. La cobertura visual de esta aplicación ha venido, gradualmente, ampliándose de un modo muy ilustrativo del estatus geopolítico y económico que sufre o goza cada región. Mientras que Street View, uno de los mayores 'gran hermano' actuales, incorpora imágenes de una treintena de países europeos aproximadamente, por el contrario, sólo permite ver algunos lugares de menos de una decena de países africanos, así como escasea enormemente la visibilidad de vastas regiones en Asia y Oceanía. La aplicación misma ya nos indica el mapamundi de los distintos grados hegemónicos y marginales; y nos permite, entre toda la información visual editada, explorar con los ojos instantes de vida que ocurrieron (incluso, en muchos casos, datándonos la fecha aproximada de las capturas). Esto nos propone lo siguiente: mientras se nos permite ver instantes de una acción congelados, nosotros no podemos sino escrutar con la mirada e inferir, o intuir e incluso imaginar, las historias de vida que tales imágenes desnudan sin llegar a narrar ni descubrírnoslas. Obtenemos segmentos de realidad deshilachados, y nosotros podemos atribuirles un hilo argumental; o, contando con ellos, crear posibles argumentos.

En esta aplicación se debate sensiblemente el frágil y especulativo asunto de la identidad. Cada persona visualmente capturada, figura como un elemento petrificado con el resto de un paisaje mapeado. Todas y cada una de ellas, son convertidas en un 
atrezo mudo y, de lugar en lugar, componen un mapa del mundo en silencio. Estas identidades personales quedan reducidas a lo evidente o aparecido en pantalla, o bien sujetas a las miradas que por azar las encuentren. También de este modo es como, finalmente, "nuestra identidad depende, pues, de formas construidas [...] que han devenido hegemónicas” (Martín Prada, 2018, p. 47).

La motivación estética o creativa del alumnado, la hacemos radicar precisamente aquí: en una posibilidad más de agrietar lo evidente, y enrolarse en busca de lo que Pessoa llamó "los intersticios del conocimiento"; ese lugar donde Valente sitúa "ahí, precisamente, en ese espacio intersticial [...] la obra de arte" (Valente, 2008, pp. 498-499). Una grieta o espacio, contiguo a lo mostrado y lo oculto, que ahonda más allá de esta simple y viciada dicotomía. Recobran enorme sentido las palabras de Arañó Gisbert: "El profesor es un cultivador de grietas: su misión es fracturar la realidad aparente para captar lo que está más allá del simulacro" (Arañó, 2008, p. 10).

Detallamos la propuesta practicada en concreto con los estudiantes de Educación Plástica y Visual, o Educación de las Artes Visuales y Plásticas, según denominación recibida en las distintas universidades referidas:

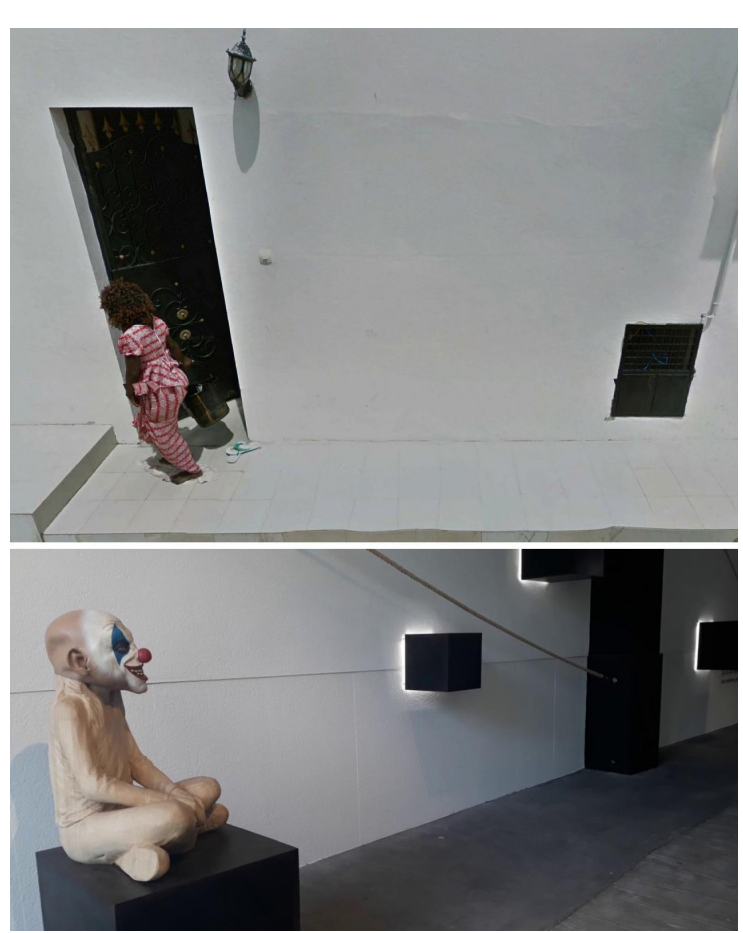

Figura 3. (Superior) Imagen, capturada de Google Street View, de una mujer que acaba de vaciar un cubo de agua en su calle, en Diammaguen, al sudeste de Dakar (Senegal), en septiembre de 2015.

Figura 4. (Inferior) Fotograma de creación en vídeo de estudiantes, con máscara de terror colocada sobre escultura en edificio público, León (España). 2019.
El planteamiento describe una primera fase en que exponemos los fundamentos teóricos comentados, y desarrollamos una relación de figuras o recursos retóricos que a la par pueden ejemplificarse con obras plásticas-visuales y poemáticas-escriturales (imagen y texto). Así, se comentan: $1^{\circ}$ ) el símbolo (valor metafórico que hila imágenes con conceptos -Redon, Toorop, Mallarmé-); $2^{\circ}$ ) la diatopía (desdoblamientos de la realidad en distintos niveles ontológicos -véanse La visión tras el sermón de Gauguin o El jinete de cobre de Pushkin, poema que trata la alienación humana-); $3^{\circ}$ ) el simultaneísmo (una fractura de los ejes narrativos de espacios y tiempos -Russolo, Balla, Severini, Feininger, Metzinger, o el poema, pionero de esto, Zonas de Apollinaire-; $4^{\circ}$ ) la condensación (esa conceptualidad reductora que, superada la sensorialidad, engendra 
imágenes metafísicas que son ya la 'imagen-objeto' de Breton, Ray, Ernst, o los textos de Tristan Tzara y Gottfried Benn); y $5^{\circ}$ ) la abstracción (en que la narratividad se ve profundamente comprometida en aras de otros valores y códigos evocadores o autosuficientes -Hilma af Klint, Kandinsky, Pollock, Gottlieb, Tobey, Mathieu, Frankenthaler, Broto, o los poemas de Paul Celan-). Éstos son algunos de los recursos retóricos que el estudiante puede tomar como herramientas para trabajar el lenguaje estético; el cual es importante que vea ejemplificado tanto en imagen como en texto: pues conviene recordar, extraído de Elogio del calígrafo, que "la pintura, en la tradición china, sea históricamente tributaria de la escritura [lo que hace] frecuente que los pintores buscaran estímulos en la lectura de poemas" (Valente, 2008 , p. 494). Tanto la imagen como el texto se asocian y convergen en un solo cuerpo, empleado el estudiante en practicar los lenguajes estéticos, para edificar un relato cuyo nivel de iconicidad puede variar sustancialmente, y donde entrarán en juego el trucaje o extrañamiento como retóricas recurrentes.

De modo que, en una segunda fase, estos contenidos se llevan a la práctica con un primer guion trazado (escrito-dibujado-fotografiado) y su posterior desarrollo videográfico (en su amplia mayoría, con el dispositivo móvil). En las producciones audiovisuales, las libertades temática y expresiva prevalecen, de manera que esto no es óbice para desplegar las ideas que con mayor interés les motiven. Paralelamente, se embarcan en un viaje exploratorio, virtual, empleando la aplicación Street View de Google para hallar y seleccionar imágenes, fotogramas, que decidan intercalar con sus propias capturas y grabaciones.

La última y tercera fase comprende el montaje o edición del material provisto mediante software de acceso con nivel de usuario básico-medio (como, por ejemplo, el Movie Maker de Microsoft o el PowerDirector de Cyberlink entre otros elegibles). Esta construcción de un relato visual requiere que cada persona articule un discurso, y otorgue un sentido, artísticos: empleando imágenes propias y ajenas, comprendiendo en la azarosa interconexión que tampoco podemos tomar el control total de lo visual. Pues le hemos cedido, al alumnado, el poder de tomar las decisiones sobre qué hacer visible, y de reconocer la sutil pero radical asimilación de crítica y condicionamiento que se compromete en nuestra mirada. Intención y descubrimiento se conjugan, al tiempo que estamos probando con qué alcance permite o restringe, nuestro entorno cibernético y digital tan fuertemente mediatizado, acciones creativas y críticas (Escaño, 2012, p. 23).

\section{El plano pedagógico de la propuesta: la metodología activa de aprendizaje basado en proyecto}

Descritas las tres fases que comprende el proyecto planteado, comentamos el plano pedagógico de esta experiencia. Al marco teórico y a la estructura de trabajo, se fundamenta una metodología activa de aprendizaje basado en los proyectos y, con ellos, en la acción decisoria de los propios estudiantes. Esta estrategia metodológica 
se adecua, en primer lugar, a la perspectiva crítica que defendemos para la Educación Artística; y en segundo lugar se corresponde con las características y tipología de la propuesta descrita y trabajada. La acción de cada estudiante, y sus colaboraciones conjuntas o grupales, vertebran su autonomía y la oportunidad de descubrir plurales soluciones creativas (narrativas visuales en este caso) que los reconoce ciudadanos con responsabilidad discursiva; a todos los efectos, sujetos éticos (Villalba, 2017) que deciden y valoran los significados de escenarios humanos capturados a través de Internet y creados-capturados mediante vídeo en el dispositivo al que se tenga acceso.

Con esta metodología garantizamos los criterios descritos por M. Esteban Guitart: la presencia de acciones o actuaciones físicas (con énfasis cuando se trata, como se ha explicado, de reflexionar las presencias y ausencias que a todos sujetos con mirada nos conciernen); la vinculación intelectual contraída en una actividad ética y estética; las vinculaciones espaciales-territoriales, contraponiendo espacios reales propios y otros remotos; una mediación instrumental versátil que cumple accesibilidad y comunicación; y bien, unos objetivos de aprendizaje flexibles en tanto dependen de la corresponsabilidad discente-docente durante el proceso del proyecto (Guitart, 2011, pp. 97-98).

En este sentido, los factores condicionantes de aprendizaje no provienen tanto de la instrucción en el aula sino del mundo explorado afuera (los espacios elegidos por los estudiantes para sus acciones videográficas y en muchos casos intervenciones, y los espacios azarosamente encontrados en la Red, según el plan de trabajo ya descrito). Los contenidos conceptuales guían y contextualizan la propuesta, pero la clave de ésta ha radicado en la actividad desarrollada y en el relato visual implicado; defendiendo los valores de la autonomía y de la intersubjetividad con que cada alumna y cada alumno personifica sin titubeo su proceso de localizar información, identificar/empatizar, y valorar elementos encontrados o extraídos (Mora, Salazar y Palíz, 2019, p. 25).

Bajo esta metodología y estructura de trabajo, así como con los objetivos señalados -entrenar un lenguaje estético-visual, y generar un discurso ético-político a partir de narrativas visuales-, los estudiantes han participado en grupos normalmente formados por cuatro personas. Tanto un alumnado compuesto por 83 estudiantes (en el curso 2018/2019 en la Universidad de León) como otro conjunto de 51 estudiantes (en el curso 2017/2018 en la Universidad de Sevilla), han descrito un total de 21 grupos y de 13 grupos de trabajo respectivamente. Del entorno a las 45 sesiones lectivas que el calendario académico otorga a la asignatura, el proyecto ha ocupado 6 sesiones para la primera fase (fundamentación teórica), 12 sesiones combinadas con el avance de temario para la segunda fase (guionizar, proponer espacios y localizaciones, y orientar aspectos de forma y contenido), y 3-5 sesiones finales (según número de grupos) reservadas para el visionado, la discusión y coevaluación de los proyectos. Quedando la tercera fase (montaje y edición de 
DOMÍNGUEZ / El fenómeno de la mirada y el concepto de lugar. Una propuesta de aprendizaje basado en proyecto con videocreación e Internet

vídeo, así como las grabaciones de la segunda fase) destinada a las horas de trabajo que el estudiante dedica a la asignatura fuera del aula. De ambas experiencias académicas archivamos el material audiovisual creado por cada grupo y rúbricas de coevaluación entre grupos, abiertas e individuales, donde reflejar tres cuestiones: $1^{\text {a) }}$ "¿Qué ideas te sugiere el relato visual proyectado, tal cual es su contenido audiovisual?”; 2a "¿Qué ideas te sugiere, confirma, o contradice, el mismo tal como lo han explicado sus autoras y autores?”; y $3^{\mathrm{a}}$ ) “QQué otro relato cabe en ese vídeo si la mirada depende de ti?".

Los resultados más relevantes de las acciones experimentadas, han descrito una prevalencia del lenguaje surrealista, del uso del simbolismo mediante objetos aportados por las alumnas y alumnos, del uso del texto literario (propio o tomado de otros autores para sustentar mensajes), del aprovechamiento de elementos artísticos urbanos (pintadas de grafiti, planos arquitectónicos,...), y en especial del
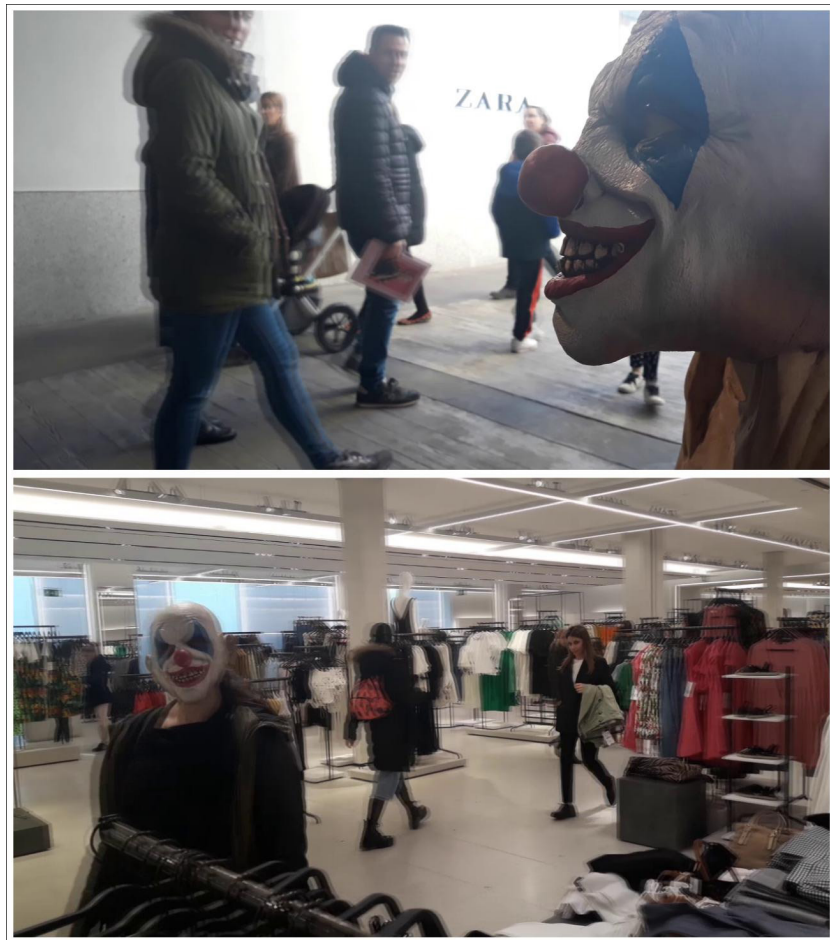

Figura 5. (Superior) Fotograma de creación en vídeo de estudiantes, con máscara terrorífica de payaso colocado en la via urbana.

Figura 6. (Inferior) Fotograma de creación en vídeo, con una de las alumnas portando lamáscara mientras deambula en un centro comercial. 2019. aprovechamiento de elementos humanos y sociales no controlados (concurrencia de personas en distintos espacios públicos, comerciales, o eventos). En cuanto a los argumentos, han prevalecido temas que describen problemáticas sociales bien identificadas (desigualdad visible en la dinámica de una ciudad, falta de accesibilidad con motivo de barreras urbanas o arquitectónicas, el comportamiento vial condicionado por el mobiliario urbano que se disponga, etc.); y también aquellos otros argumentos poéticos empleando en muchos casos la intertextualidad texto-imagen (la alienación, la degradación de elementos paisajísticos, el azar de encuentros y desencuentros anónimos, lo efímero, etc.).

\section{Consideraciones finales y toma de conciencia}

De estas experiencias pioneras, motivación para guiar una dirección de trabajo en que avanzar en el Grado en Educación Primaria, hemos observado y aprendido 
que el 'juego creativo' resulta fructífero para el estudiante cuando se intensifican los elementos que están en juego (no sólo formales o estéticos). Y también la consideramos extensible y viable, por esta razón, en otras asignaturas del área, de carácter optativo como talleres de expresión artística, que existen en los grados de Educación Social y Pedagogía.

En los diferentes grupos de trabajo formados para abordar este proyecto, en que han abundado los lenguajes y argumentos referidos, queremos resaltar como ejemplo -en el espacio de este trabajo- el caso de videocreación titulada Destrucción [Alienación], cuyo sugerente relato visual juega con la alegoría de una máscara terrorífica de payaso, que las alumnas de la Universidad de León explican significar el miedo y la despersonalización en un ambiente de extrañamiento social. Para ello han intercalado imágenes tomadas de Internet, como señalamos, con una serie de grabaciones hechas en lugares públicos en los que habían infiltrado este elemento inquietante. Tejen así la metáfora del cuestionamiento de nuestras identidades en una comunidad movida por la inercia (la que mueve a la gente en centros comerciales y lugares semejantes). Las estudiantes, autoras, lo explican como una reflexión y advertencia acerca de la identidad de la persona (cuyo étimo, recordemos, es 'máscara de actor'), plasmada en la terrorífica máscara de payaso (principal elemento vinculante que hila el mensaje) y en cuantos rostros y cuerpos figuran, cercanos o remotos, diluidos en un anonimato general; ya se trate de personas que pasean con sus compras en la misma ciudad donde las estudiantes intervienen y viven, o de una mujer anónima que acaba de vaciar un cubo de agua en las calles de Diammaguen al sudeste de Dakar (Senegal). Extrañando una sucesión lógica de imágenes, logran perder su ilación original para tomar referentes como propios y otorgar un sentido en que las cosas se resignifican. El conjunto del alumnado, a través de las videocreaciones de sus compañeras y compañeros, toma conciencia de las posibilidades alternativas del lenguaje estético, en primer lugar, y del poder hegemónico que también se ejerce como hegemonía visual con la mirada, pudiéndose tanto evanescer como recuperar esquirlas de realidad que circulan por el ciberespacio -y que, tratándose de las imágenes propias facturadas, podemos hacer circular también-.

En esta práctica artística, hacer y decidir son verbos que se conjugan a la par. Las competencias, cognitiva, estético-narrativa, crítica (en lo social y político que entraña) e instrumental (en el uso digital tanto de la tecnología propia como disponible en Internet) se desarrollan con igual importancia para engranar el proyecto que se propone. Una investigación de cuyo aprendizaje estudiantes y docente continuamos sumando y descubriendo lo desapercibido, llevando el espacio educativo, fuera del aula a lugares o exteriores escogidos, itinerante. Lo vivencial exige el rasgo ubicuo que esta práctica nos manifiesta, planteando las preguntas y respuestas que urgen hacerse como parte del proceso emancipatorio al que podemos contribuir. 
DOMÍNGUEZ / El fenómeno de la mirada y el concepto de lugar. Una propuesta de aprendizaje basado en proyecto con videocreación e Internet

\section{Referencias}

Arañó, J. C. (2008). Presentación. En F. Maeso et al (Coord.), Educación Artística y Visual. El Reto Social, Cultura y Territorialidad. (pp. 9-10). Sevilla: COLBBAA.

Aumont, J. (1992). La imagen. Barcelona: Paidós.

Bergson, H. (2001). Matière et mémoire. Essai sur la relation du corps a l'esprit. En A. Robinet y H. Gouhier (Comp.), Euvres (6 édition). (pp. 169-223) París: Presses Universitaires de France.

Bozal, V. (1987). Mímesis: las imágenes y las cosas. Madrid: Antonio Machado.

Brea, J. L. (2007). Cambio de régimen escópico: del inconsciente óptico a la e-image. Estudios Visuales: Ensayo, teoría y crítica de la cultura visual y el arte contemporáneo, 4, 146-163.

Brea, J. L. (2010). Las tres eras de la imagen. Imagen-materia, film, e-image. Madrid: Akal.

Brihuega, J. (2002). Las vanguardias artísticas: teorías y estrategias. En V. Bozal (Ed.), Historia de las ideas estéticas y de las teorías artísticas contemporáneas (Volumen II). (pp. 229-248). Madrid: Antonio Machado.

Bryson, N. (1991). Visión y pintura. La lógica de la mirada. Madrid: Alianza.

Debord, G. (2016). La sociedad del espectáculo. Valencia: Pre-textos.

Eco, U. (1990). Obra abierta. Barcelona: Ariel.

Escaño, C. (2010). Hacia una educación artística 4.0. Arte, Individuo y Sociedad, $22(1), 135-144$.

Escaño, C. (2012). Desarrollando una P2Pedagogía Artística. Propuesta educativa horizontal desde una pedagogía crítica artística y mediática: desarrollo de proyecto web documental basado en relaciones pedagógicas P2P. EARI, 3, 17-30.

Escaño, C. (2019). La mirada como acto político. El cine y otros audiovisuales como herramientas educativas de (re)construcción del mundo. EARI, 10, 251-261.

Francastel, P. (1988). La figura y el lugar. Barcelona: Laia.

Fried, M. (2004). Arte y objetualidad. Ensayos y reseñas. Madrid: Antonio Machado.

Gadamer, H.-G. (2010). La actualidad de lo bello. Barcelona: Paidós \& UAB.

González, A., Calvo, F. y Marchán Fiz, S. (2009). Escritos de arte de vanguardia. Madrid: Akal \& Istmo. 
Guitart, M. E. (2011). Del "Aprendizaje Basado En Problemas" (ABP) al "Aprendizaje Basado En La Acción" (ABA). Claves para su complementariedad e implementación. Revista de Docencia Universitaria, 9(1), 91-107.

Jiménez, J. (2002). Teoría del arte. Madrid: Tecnos \& Alianza.

Klee, P. (2007). Teoría del arte moderno. Buenos Aires: Cactus.

Liddell, A. (2015). La indignación hace versos. En O. Cornago y S. Cendal (Eds.), El sacrificio como acto poético. (pp. 45-57). Madrid: Continta Me Tienes.

Martín Prada, J. (2018). El ver y las imágenes en el tiempo de internet. Madrid: Akal.

Merleau-Ponty, M. (2010). Lo visible y lo invisible. Seguido de: Notas de trabajo. Buenos Aires: Nueva Visión.

Mora, W.; Salazar, L.; Palíz, C. (2019). El Aprendizaje Basado en Proyecto: realidad y perspectivas. Revista Ciencia e Investigación, 4(4), 22-33.

Orwell, G. (1983). 1984. Barcelona: Salvat.

Rothko, M. (2007). Escritos sobre arte (1934-1969). Barcelona: Paidós.

Valente, J. A. (2008). Elogio del calígrafo. Ensayos sobre arte. En A. Sánchez Robayna (Ed.), Obras completas II. Ensayos. (pp. 473-600). Barcelona: Galaxia Gutenberg.

Villalba, S. (2012). Educando en la indignación: imagen y acción desde la minoría. En D. Callejón e I. M. Moreno (Eds.), Arte, Educación y Cultura. Aportaciones desde la periferia. Recuperado de http://www.educacionartistica.es/aportaciones/1 comunicaciones/politizacion/109_villalba_educando_indignacion.pdf

Villalba, S. (2017). Conexiones artísticas, éticas y educativas: una trayectoria consolidada. En C. Escaño (Ed.), Investigación en Educación Artística (What are you looking at?). (pp. 179-183). Sevilla: ECAV. 